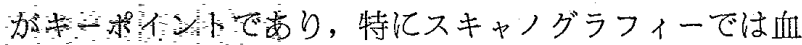

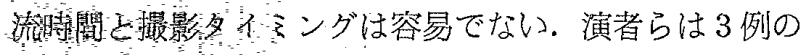

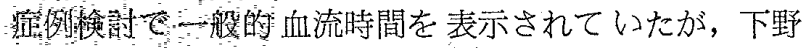

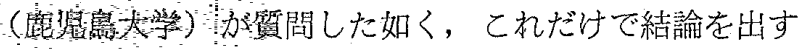

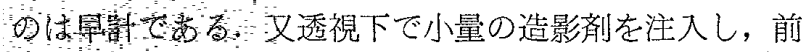

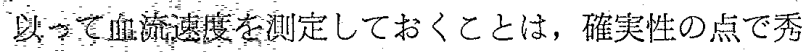

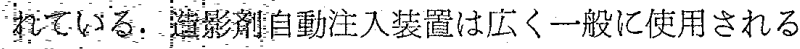

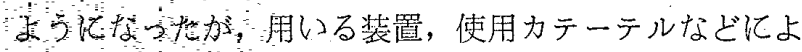

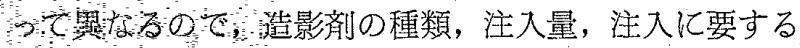

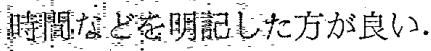

湍晒120 Gasmgelography は最近，また脚光を浴び

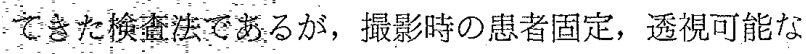

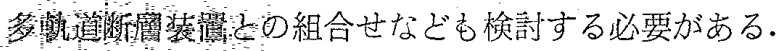

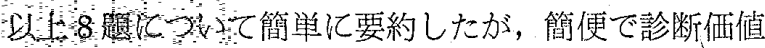

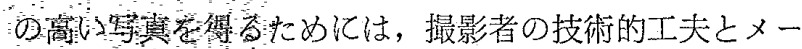

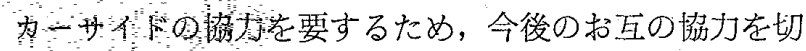

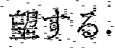

\section{測定法 (撮影領域)}

座長 小林 让敏（関果厐信病院）

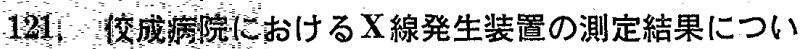
c

咅国度成会附属佼成病院

O事戸 哲也・神田 幸助・斉滕 一彦 野口博・工藤 和美・斉藤 文男 碎野伸一・杉山䇪・渡辺雅弘 童沢 常睛

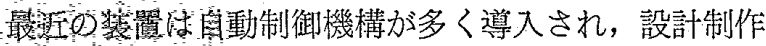

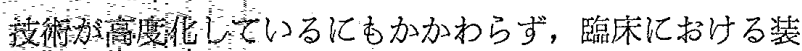

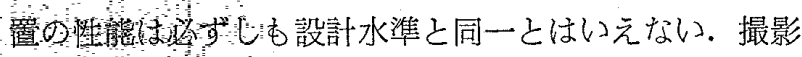

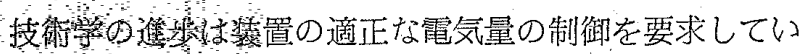

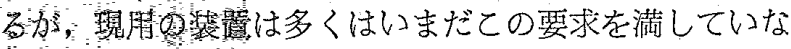

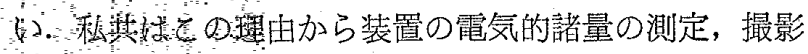

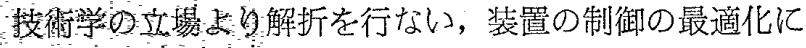

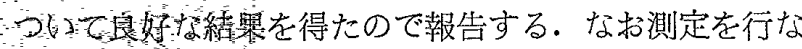

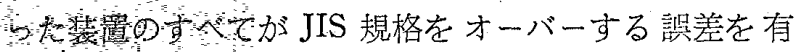

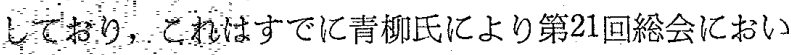

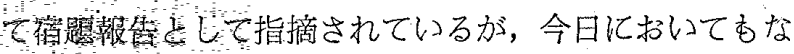

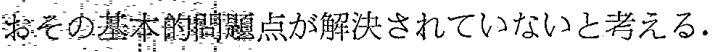

\section{2 速国輊定トロボ像による高圧現象の解析}

\section{主威戝成会附属佼成病院}

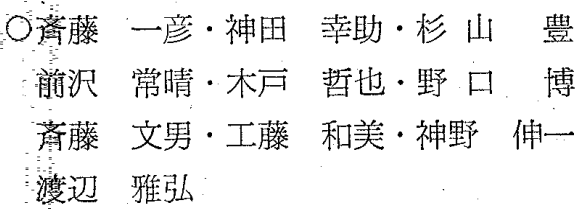

東邦大学 医学部放射線医学教室

青楖 泰司

近時，大容量X線管の普及之共に曝射時間はより短時 間になる傾向である。しかるに，50 ms 以下の短時間撮 影に执してはX線発生装置の動作特性を客観的に把握し なければ確実な撮影を行ない得ない。我々は，従来曝射 時間の測定にのみ用いられていたX線コマの像に着目し， 同期電動機により一定速度でのストロボ像を得る定速回 転X線ストロボスコープを試作し，得られたストロボ像 をX線管電圧波形，増感紙螢光強度波形オシログラムと 対比検傠した。

〔結論】

定速ストロボ像はX線発生時のサージ等高電圧現鱼を 忠実に現出していることが証明された．本装置により高 電庄回路に一切手を触れるととなくX線発生時の装置動 作状態を知ることができる。

\section{3． 熱螢光線量計の方向特性について}

国立公俰衛生院 放射線衛生学部 遠藤：幸一

骖断領域のX線エネルギーに対するTLDの感度のば らつきについて，素子そのものの吸収によるレスポンス が素子の計測面により異なるととに着目し，X線の照射 面と透過面を棓測した。

[結果】

$\mathrm{CaSO}_{4}$ ：Tm (UD-110S．松下電器製）では，照射面 に対し透過面の線量值は $13 \sim 20 \%$ 低く，1\%以下の有 意水準で有意な差が認められた。

央效原子番号の低い $\mathrm{BeO}$ (UD-170A）では 2.5 4.1 \%程度の善で有意な差は諗められなかった。とくに素子 の照射面を定め計測すれば各素子の再現性もよく, 素子 闠のばらつきも少なくなる。同時に，㑑人被曝管理用線 量計のエネルギー特性補償用金属シールドの構造および 素子の方向性についても汾な教慮が必要である。

\section{4. 欠題}

125. 欠題

126. 螢光量計受光部の検討

東邦大学医学部附属大森病院
○町田 㤵一・泉 重 光・森口 康生

\section{座長集約}

この部門は，六題中三題が欠題となり，実際には四題 の報告となった．演題 121 てでは一矩設に括いて同じ撮影 条件でも装置が異なるとX線装置が変化するという装置 の基本的な性能等について三台の前示装置について実測 した結果前示值と奏測值に違いがあることが主たる原因 